\title{
Ankitudigurn.
}

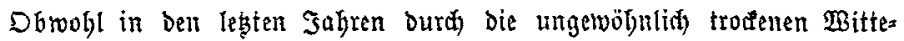

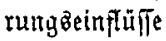

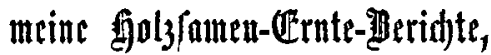

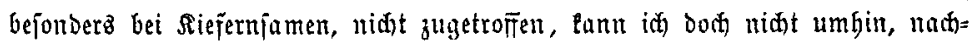

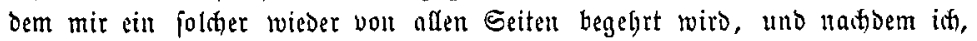

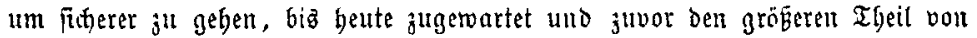
Deutioland bereizt babe - einell folthent wieber jul gebert.

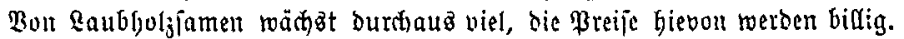

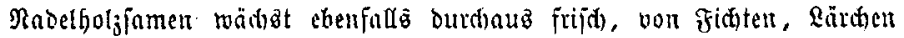

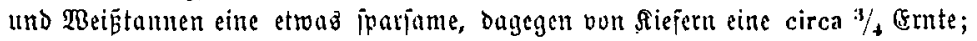

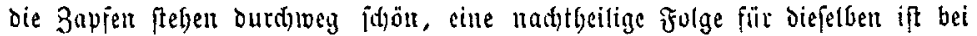
Dér yorgerüften Sabregijeit foum melgr ja befürthter.

(5z buirfte Duber

Fithten olgne Flügel niaht über 10-12 Pr. $=3-4$ Sgr.

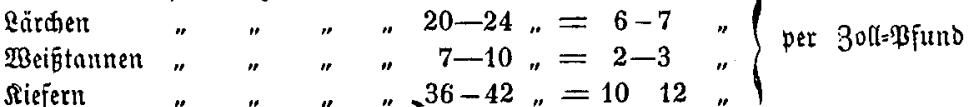

stiefern "

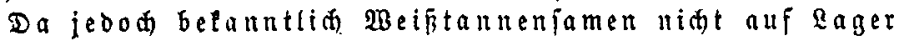
genommen werben tann, erlaube in ergebent gubitter, mir bies

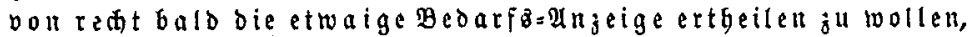
da íg gemín nur babei die billigften Preije berednen merde.

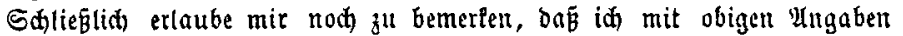

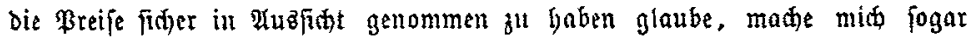
verbindtian, Geute fron afufträge in biejelt Samen angunehmen.

Im Uebrigen werde inf im Eaufe des Monatz Sanuar 1861 mir erlauten, die genuueften Preife noch mitzatbeilen, die iđh, mie immer, neben einer vor=

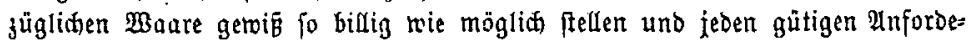
rungen beften entipreden werbe.

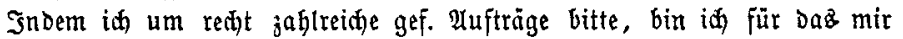
jeither gütigit geiłhenfte Bertrauen vou serjen banfbar und verbarre mit aller 5̧0(j)adtung

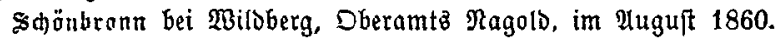

(im wittt. Safmargmalbe.)

ergebenfter

\section{Gigr. OEetgle.}

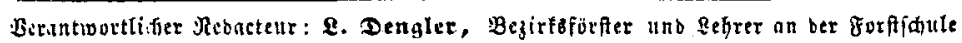

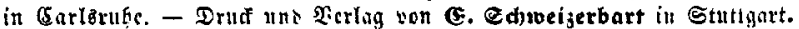

